\title{
EVALUASI KEBIJAKAN PERATURAN BAZNAS NOMOR 2 TAHUN \\ 2016 TENTANG PEMBENTUKAN DAN TATA KERJA UNIT \\ PENGUMPUL ZAKAT DI UNIVERSITAS PADJADJARAN
}

\author{
${ }^{1}$ Nanang Suparman, Wildan Romadhon \\ ${ }^{1}$ Fakultas Ilmu Sosial dan Ilmu Politik, UIN Sunan Gunung Djati Bandung; n.suparman69@ @mail.com
}

\begin{abstract}
This study aims to find out and describe the process of implementing the UPZ implementation policy evaluation at Padjadjaran University: Factors that have constrained the evaluation of UPZ policies at Padjadjaran University: and the implications of the constraints on the existence of UPZ Padjadjaran University. This study uses policy evaluation theory from William. N. Dunn who said that policy evaluation is influenced by six dimensions. The research method used is a qualitative approach with a type of descriptive method. Techniques for collecting data through interviews, observation and literature. Based on the results of the study, it was found that the policy evaluation of the Central Baznas Regulation Number 2 of 2016 had not yet run optimally. This is because there are still among Muzaki who have potentially not participated in the UPZ Unpad and mustahik who have not all felt satisfaction with the service and provision of infaq and charity zakat funds. In addition, the human resources available at UPZ Unpad are still limited, especially in the ranks of the management.
\end{abstract}

Keywords: Public Policy, Policy Evaluation, Effectiveness, Efficiency 


\section{Pendahuluan}

Zakat bagi umat Islam merupakan salah satu kewajiban yang harus ditunaikan, setelah terpenuhi syarat dan pelaksanaannya sebagaimana yang dikemukakan oleh Syu'aibun, zakat adalah ibadah fardhiyah yang berimplikasi luas dalam kehidupan sosial, ekonomi, politik, budaya, pendidikan sehingga meliputi pemahaman tentang konsep pemilikan harta, ekonomi, dan keadilan dalam berbagai dimensi (Hafidhuddin, 2002:8).

Di dalam ajaran Islam pun, zakat adalah rukun Islam yang pokok dan mendasar, sebagaimana tercantum dalam Al Qur'an surat at-Taubah Ayat 103 bahwa tujuan zakat adalah untuk membersihkan dan mensucikan diri yang ayatnya berbunyi: “Ambillah zakat dari sebagian harta mereka. Dengan zakat itu kamu membersihkan dan mensucikan mereka. Dan berdoalah untuk mereka. Sesungguhnya doa kamu itu (menjadi) ketentraman jiwa bagi mereka. Dan Allah Maha Mendengar lagi Maha Mengetahui”(Q.S at-Taubah:103).

Umat Islam dalam hal ini perlu mewujudkan stabilitas umat disekitarnya dengan cara menghidupkan zakat sebagaimana mestinya. Zakat perlu diatur dan dikelola secara baik sehingga akan meminimalisir permasalahan umat terkhusus masalah ekonomi hal ini termaktub pada Undang Undang Nomor 23 Tahun 2011 tentang Pengelolaan Zakat.

Salah satu instansi di Jawa Barat yang sesuai dengan keberadaannya adalah Badan Amil Zakat Nasional Provinsi Jawa Barat. Demi lancarnya tugas dari instansi maka Baznas pusat mengeluarkan sebuah kebijakan yang tertuang didalam peraturan Baznas salah satunya Peraturan Nomor 2 Tahun 2016 Tentang Pembentukan dan Tata Kerja Unit Pengumpul Zakat (UPZ). UPZ adalah satuan organisasi yang dibentuk oleh Badan Amil Zakat di semua tingkatan dengan tugas mengumpulkan zakat untuk melayani muzakki (orang yang berhak 
menerima zakat), yang berada pada desa/kelurahan, lembaga-lembaga pemerintah dan swasta, baik dalam negeri maupun luar negeri (pusat.baznas.go.id).

Peraturan Nomor 2 Tahun 2016 dalam pasal 4 ayat 1 huruf (e) bahwa Baznas Provinsi membentuk UPZ provinsi pada institusi perguruan tinggi, pendidikan menengah, atau nama lainnya. Baznas ditingkat provinsi dapat membentuk UPZ di perguruan tinggi yang tidak dapat dibentuk oleh Baznas Pusat dan Kabupaten/Kota. Perbedaan ini menjadi satu titik temu yang amat penting bagi keberadaan UPZ dalam ruang lingkup lembaga pendidikan setingkat perguruan tinggi. Elemen penting yang masuk dalam kategori mustahik di tataran perguruan tinggi adalah mahasiswa dan karyawan, karena mahasiswa masuk dalam kategori fi sabilillah dan fakir miskin serta karyawan yang mengalami masalah finansial.

Salah satu UPZ yang berada dalam wewenang Baznas Provinsi Jawa Barat sekaligus UPZ yang pertama kali dibentuk oleh Baznas Jawa Barat di tataran perguran tinggi serta memiliki peta rancangan dan susunan dengan target utamanya menjadi standar acuan pengelolaan unit penghimpun zakat di perguruan tinggi, terutama di PTN (Perguruan Tinggi Negeri) Badan Hukum pada 2020 mendatang adalah UPZ Universitas Padjadjaran (jabartribunnews.com: 2017).

Dana zakat infak dan sedekah tersebut dihimpun oleh UPZ Unpad dalam sebulan yang digabungkan melalui pemotongan gaji, remunerasi dan sertifikasi gaji pegawai dan dosen terhitung pada bulan Maret 2018 sebagai berikut: 
Tabel 1.1

Dana Zakat, Infak dan Sedekah UPZ Universitas Padjadjaran

\begin{tabular}{|l|l|l|l|c|l|}
\hline No & Metode & Zakat & Infak & Sedekah & Jumlah \\
\hline 1. & Payroll System & - & - & - & Rp.0 \\
\hline 2. & Remunerasi & Rp. 12.979.068 & Rp. 2.300.905 & - & Rp. 15.279.973 \\
\hline 3. & Sertifikasi & Rp. 2.382.462 & - & - & Rp. 2.382.462 \\
\hline \multicolumn{7}{|c|}{ Total } & Rp. 17.662.435 \\
\hline
\end{tabular}

Sumber: UPZ Unpad (Maret: 2018)

Tahap penyaluran/pendistribusian zakat infak dan sedekah ini telah ditentukan oleh pihak UPZ Unpad yang didistribusikan melalui dua program. Pertama, program cinta literasi yang dibagi menjadi dua; (a) Cinta kata: yakni program peningkatan literasi keislaman melalui beasiswa uang buku sebesar Rp. 100.000/bulan, (b) Cinta Qur'an: Pembinaan musyrif/ah Lembaga Pengembangan Tilawatil Qur'an untuk mendapatkan sanad keilmuan. Kedua, program santunan.

Pendistribusian zakat, infak dan sedekah kepada para mustahik yang dilakukan oleh UPZ Universitas Padjadjaran terbagi kedalam pembagian sebagai berikut:

Tabel 1.2

Alokasi dana zakat, infak dan sedekah kepada mustahik

\begin{tabular}{|l|l|l|l|l|}
\hline No & Asnaf & Alokasi & Target Internal & Target Eksternal \\
Kampus & Kampus \\
\hline 1. & Fakir & $15 \%$ & 10 & 90 \\
\hline 2. & Miskin & $15 \%$ & 50 & 50 \\
\hline
\end{tabular}




\begin{tabular}{|l|l|l|l|l|}
\hline 3. & Amil & $15 \%$ & 100 & 0 \\
\hline 4. & Fisabilillah & $40 \%$ & 90 & 10 \\
\hline 5. & Ibnu Sabil & $10 \%$ & 50 & 50 \\
\hline 6. & Mualaf & $5 \%$ & 50 & 50 \\
\hline
\end{tabular}

Sumber: UPZ Unpad (Infografis: 2017)

Pembagian dana zakat, infak dan sedekah serta program program yang ada di UPZ Unpad masih belum benar benar memecahkan problem inti yang dialami oleh masyarakat internal kampus (mahasiswa dan karyawan) di dalam mengentaskan kemiskinan secara keseluruhan. Sebagaimana yang dikemukakan oleh Al Qardhawi (2005: 30) bahwa "secara umum tujuan pokok dari pelaksanaan zakat adalah untuk menanggulangi kemisikinan secara menyeluruh". Dengan demikian, zakat memiliki peran yang sangat penting dalam perbaikan kesejahteraan masyarakat. Program tersebut hanya program rutinan biasa yang tidak melihat mahasiswa/i dan karyawan mana yang benar benar membutuhkan dan sedang mengalami masalah finansial yang serius.

Beberapa agenda untuk melakukan evaluasi telah dilakukan oleh pihak Baznas Provinsi maupun dari pengurus UPZ nya itu sendiri yang mengacu pada landasan peraturan Baznas Nomor 2 Tahun 2016 tentang pembentukan dan tata kerja Unit Pengumpul Zakat. Adapun pelaksanaan dilapangan seperti yang dikemukakan diatas, didalam cara pengelolaannya, pendistribusian dan pendayagunaannya masih belum optimal sehingga beberapa asnaf tidak terbagi dengan rata dan untuk evaluasi selalu membahas mengenai hal tersebut. Evaluasi yang telah dilakukan oleh yang berwenang memberikan perbaikan perbaikan dan menilai sejauh mana kinerja pelaksanaannya terhadap kebijakan yang telah dibuat/ target yang seharusnya terjadi dilapangan. 
Evaluasi proses yang dilakukan dengan demikian adalah untuk melihat seberapa jauh kegiatan yang dilaksanakan, sudah terlaksanan sesuai rencana (Suparman,2018). Kemudian juga evaluasi ini ditujukan untuk melihat seberapa efektif kebijakan publik dilaksanakan oleh pihak yang mempunyai wewenang sehingga hal tersebut dapat dipertanggungjawabkan kepada masyarakat. Secara garis besar, Anderson (1975) dalam Winarno (2008) mendefinisikan evaluasi kebijakan sebagai aktivitas yang menggambarkan proses penilaian terhadap suatu kebijakan atau program yang melingkupi konten atau isi, implementasi atau pelaksanaan, dan pengaruh atau dampak dari implementasi kebijakan tersebut. Tujuan utama dari evaluasi kebijakan ini sebenarnya adalah bukan dalam rangka mencari kambing hitam atau menyalahkan seseorang atau sekelompok orang, melainkan untuk memperoleh pengetahuan seberapa besar dan seberapa baik tingkat ketercapaian dan tujuan dari sebuah kebijakan publik (Nugroho, 2014).

Evaluasi kebijakan pada dasarnya memiliki sejumlah ciri identik yang berbeda dengan beberapa metode analisis kebijakan yang lainnya. Ciri-ciri identik tersebut, menurut Dunn (2003) diantaranya adalah:

1. Fokus pada nilai, yaitu evaluasi ini berkenaan dengan penilaian tentang kebutuhan yang didasari atas nilai-nilai dari sebuah kebijakan atau program. Evaluasi ini pasti akan selalu membahas sekaligus mempertanyakan ketercapaian sasaran dari kebijakan atau program, sehingga kegiatan evaluasi melingkupi sejumlah cara dan prosedur untuk menilai tercapai atau tidaknya sarsaran tersebut.

2. Saling ketergantungan antara fakta dan nilai, yaitu untuk dapat mengetahui ketercapaian kinerja tinggi atau rendah, maka diperlukan sejumlah bukti atau catatan yang mendukung bahwa hasil-hasil kebijakan secara riil merupakan akibat 
dari tindakan-tindakan untuk mengatasi isu-isu tertentu. Oleh karenanya, monitoring adalah prasyarat dari evaluasi tersebut.

3. Orientasi masa kini dan masa lalu, yaitu bahwa evaluasi ini memiliki sifat retrospektif dan ex-post dan juga bersifat prospektif dan $e x$-ante. Hal tersebut bisa dilihat dari misalnya sebuah rekomendasi yang melingkupi catatan-catatan penuh akan nilai hasil dari aktivitas penilaian, dan kemudian akan diberlakukan untuk mendukung kegiatan atau program lainnya kedepan.

4. Dualitas nilai, yaitu karena evaluasi ini dilihat sebagai sebuah tujuan juga sebuah cara. Evaluasi bisa dikatakan sama dengan rekomendasi apabila mereka berkenaan dengan nilai yang ada, misalnya yaitu kesehatan yang dianggap sebagai sesuatu yang bersifat intrinsik (diperlukan bagi dirinya) ataupun ekstrinsik (diperlukan karena dapat mempengaruhi tercapai tidaknya tujuan lain).

Penelitian ini mengaplikasikan sebuah teori evaluasi kebijakan dari Dunn. Secara umum Dunn dalam (Nugroho, 2009) memberikan penjelasan mengenai indikator-indikator dalam proses evaluasi terhadap suatu kebijakan. Pertama, yaitu: Efektifitas; apakah hasil yang diinginkan dapat tercapai? Kedua, Efisiensi; seberapa besar usaha untuk mencapai hasil yang ingin dicapai? Ketiga, Kecukupan; seberapa jauh pencapaian hasil yang dihendaki dapat mengatasi suatu masalah? Keempat, Perataan; apakah biaya yang diperoleh dari manfaat dapat didistribusikan dengan merata kepada kelompok-kelompok yang berbeda? Kelima, Responsivitas; apakah hasil kebijakan dapat memuaskan kebutuhan, preferensi, atau nilai kelompok-kelompok tertentu? Kenam, Ketepatan; apakah hasil yang diinginkan benar-benar berguna atau bernilai? Dari beberapa definisi yang telah dijelaskan dapat ditarik kesimpulan bahwa evaluasi kebijakan merupakan suatu kegiatan yang dilakukan dalam rangka melihat 
implementasi kemudian melakukan penilaian terhadap jalannya suatu kebijakan apakah kebijakan sudah terealisasi dengan baik atau belum, adapun tujuan dari evaluasi ialah untuk mengetahui apakah kebijakan tersebut layak untuk dilanjutkan atau tidak. Di bawah ini adalah kriteria kebijakan menurut Dunn:

Tabel 1.3

Tipe Tipe Evaluasi Kebijakan Menurut Dunn

\begin{tabular}{|c|c|c|}
\hline Tipe Kriteria & Pertanyaan & Ilustrasi \\
\hline Efektivitas & $\begin{array}{l}\text { Apakah hasil yang diinginkan telah } \\
\text { dicapai }\end{array}$ & Unit pelayanan \\
\hline Efisiensi & $\begin{array}{l}\text { Seberapa banyak usaha diperlukan untuk } \\
\text { mencapai hasil yang diinginkan? }\end{array}$ & $\begin{array}{l}\text { Unit biaya, manfaat bersih, } \\
\text { rasio cost benefit }\end{array}$ \\
\hline Kecukupan & $\begin{array}{l}\text { Seberapa jauh pencapaian hasil yang } \\
\text { diinginkan memecahkan masalah? }\end{array}$ & $\begin{array}{l}\text { Biaya tetap Efektivitas } \\
\text { tetap }\end{array}$ \\
\hline Perataan & $\begin{array}{l}\text { Apakah biaya manfaat didistribusikan } \\
\text { dengan merata kepada kelompok } \\
\text { kelompok yang berbeda? }\end{array}$ & $\begin{array}{l}\text { Kriteria Pareto, kriteria } \\
\text { Kaldor-Hicks, kriteria } \\
\text { Rawls. }\end{array}$ \\
\hline Responsivitas & $\begin{array}{l}\text { Apakah hasil kebijakan memuaskan } \\
\text { kebutuhan, preferensi, atau nilai-nilai } \\
\text { kelompok-kelompok tertentu? }\end{array}$ & $\begin{array}{l}\text { Konsistensi dengan survey } \\
\text { warga Negara }\end{array}$ \\
\hline Ketepatan & $\begin{array}{l}\text { Apakah hasil (tujuan) yang diinginkan } \\
\text { benar-benar berguna atau bernilai. }\end{array}$ & Program \\
\hline
\end{tabular}

Sumber: William N. Dunn, Pengantar Analisis Kebijakan Publik (2000:610) 
Evaluasi biasanya ditujukan untuk menilai sejauh mana keefektifan kebijakan publik yang di tentukan oleh pemerintah/pejabat lainnya guna dipertanggung jawabkan sebagaimana mestinya kepada konstituen.

Tabel 1.4

Pendekatan Evaluasi Kebijakan Dunn

\begin{tabular}{|c|c|c|c|c|}
\hline Pendekatan & Tujuan & Asumsi & Bentuk-bentuk & Telrwils \\
\hline Evaluasi semu. & $\begin{array}{l}\text { Menggumakan } \\
\text { metode deskriptif } \\
\text { untuk } \\
\text { menghasilkan } \\
\text { mformasi yang } \\
\text { valid tentang hasit } \\
\text { kebijakan }\end{array}$ & $\begin{array}{l}\text { Uhuran manfiat } \\
\text { atau nilai terbukti } \\
\text { dengen sendirinya } \\
\text { atan tidak } \\
\text { sontroversial }\end{array}$ & $\begin{array}{l}\text { - Eksperimental } \\
\text { sosial } \\
\text { - Akun tansi } \\
\text { sistem sosial } \\
\text { - Pemeriksan } \\
\text { sosial. } \\
\text { - Sintesis risset } \\
\text { dan praktik }\end{array}$ & $\begin{array}{l}\text { - Sajian grafik } \\
\text { - Tampilan tabel } \\
\text { - Angka indeks } \\
\text { - Analisis seri waktu } \\
\text { terinterupsi } \\
\text { - Analissis seri } \\
\text { terkontrol } \\
\text { - Analisis } \\
\text { diskontinyu } \\
\text { regresi. }\end{array}$ \\
\hline $\begin{array}{l}\text { Evaluasi } \\
\text { formal }\end{array}$ & $\begin{array}{l}\text { Menggumakan } \\
\text { metode deakriptif } \\
\text { untuk } \\
\text { menghasilkan } \\
\text { info.rmasi yang } \\
\text { terpercaya dan } \\
\text { valid mengenai } \\
\text { hasil kebijakan } \\
\text { gecara formal } \\
\text { diumuman } \\
\text { gebegai tujuan } \\
\text { program- } \\
\text { kebjakan }\end{array}$ & $\begin{array}{l}\text { Tujuan dan } \\
\text { gasaran } \\
\text { perganbil } \\
\text { cebijakan dan } \\
\text { administrator } \\
\text { yang secara resmi } \\
\text { diumumkan } \\
\text { merupakan } \\
\text { gkuran yang tepat } \\
\text { dari manfaat atau } \\
\text { milai }\end{array}$ & $\begin{array}{l}\text { - Evaluasi } \\
\text { perkembangan. } \\
\text { - Evaluasi } \\
\text { ekrperimental } \\
\text { - Evaluasi proses } \\
\text { retrospektif } \\
\text { (empost) } \\
\text { - Evaluasi hasil } \\
\text { retrospektif. }\end{array}$ & $\begin{array}{l}\text { - Pemetaan sasaran } \\
\text { - Klaridikasi nilai } \\
\text { - Rritik nilai } \\
\text { - Pemetaam } \\
\text { hambetan } \\
\text { - Amalisis dampak- } \\
\text { silang } \\
\text { - Discounting }\end{array}$ \\
\hline $\begin{array}{l}\text { Evaluasi } \\
\text { Keputusan } \\
\text { tearitis }\end{array}$ & $\begin{array}{l}\text { Menggumakan } \\
\text { metode deakriptif } \\
\text { untuk } \\
\text { menghasilkan } \\
\text { informasi yang } \\
\text { terpercaya dan } \\
\text { valid mengenai } \\
\text { hasil kebijakan } \\
\text { pang secara } \\
\text { eksplisit } \\
\text { diinginkam oleh } \\
\text { berbagai felaku } \\
\text { kebijakan. }\end{array}$ & $\begin{array}{l}\text { Tujuan dan } \\
\text { jasaran dari } \\
\text { berbagai pelaku. } \\
\text { pang diumumkan } \\
\text { gecara formal } \\
\text { mauepun diam- } \\
\text { diam merupakan } \\
\text { gkuran yamg tepet } \\
\text { dar mantast atau } \\
\text { milai. }\end{array}$ & $\begin{array}{l}\text { - Penilaian } \\
\text { tentang dapat- } \\
\text { tidaknya di. } \\
\text { evaluasi } \\
\text { - Analisis utilitas } \\
\text { multi atribut. } \\
\text { yaitu. } \\
\text { serangbaian } \\
\text { prosedu ryang } \\
\text { diciptakn } \\
\text { untuk } \\
\text { men.gambil dari } \\
\text { para pelakn. } \\
\text { kebijakan yang } \\
\text { banyak } \\
\text { memiliki } \\
\text { pandangan } \\
\text { subjektif } \\
\text { tentang } \\
\text { probabilitas } \\
\text { terjadinya } \\
\text { sesuatu ata. } \\
\text { nilai dari hasil } \\
\text { kebijakan. }\end{array}$ & $\begin{array}{l}\text { - Brainstoming } \\
\text { - Analisis } \\
\text { argumentasi } \\
\text { - Delphi kebijakan } \\
\text { - Analiais survei- } \\
\text { pemakai, yaitu } \\
\text { seranghian } \\
\text { prosedur untuk } \\
\text { mengumpulkan } \\
\text { informasi dari } \\
\text { calon pemakai dna } \\
\text { pelabu-palaku } \\
\text { kebijaban lainmya } \\
\text { mengenai } \\
\text { evaluabilitas suatu } \\
\text { kebijaban atar. } \\
\text { program. }\end{array}$ \\
\hline
\end{tabular}

Sumber: Nugroho R 2014. Public Folicy. 
Sebelum menentukan kebijakan, hal yang prioritas untuk ditinjau dalam studi kebijakan publik adalah, apa yang menjadi dampak dari kebijakan tersebut. Bukan dilihat dari awal pelaksanaan namun diujung atau hasil final dari kebijakan. Tentu dari kegiatan evaluasi kebijakan akan mengetahui hasil akhirnya dan apakah ada kesenjangan antara harapan dan kenyataan yang terjadi. Apa yang dikemukakan oleh Jones tentu menjadi salah satu sumber yang compatible tentang evaluasi kebijakan dari para peneliti.

Evaluasi kebijakan bukan hanya sebatas menilai atau mengukur manfaat dari suatu kebijakan atau program program pemerintah namun yang paling dominan untuk dikaji lebih matang oleh para peneliti dari evaluasi kebijakan adalah bagaimana aktivitas tersebut memperoleh nilai dan manfaat yang jelas (Suharto, 2012). Selain itu, evaluasi kebijakan juga dimaksudkan agar dapat mengetahui sejauh mana kebijakan publik itu dilakukan dengan efektif dalam rangka mempertanggung jawabkan segala sesuatunya kepada masyarakat. Winarno (2008) berpendapat bahwa evaluasi kebijakan ini dapat dihubungkan dengan kegiatan yang berkenaan dengan estimasi kebijakan yang melingkupi konten, pelaksanaan, dan akibat yang ditimbulkan dari kebijakan yang dilaksanakan tersebut.

Sebagaimana mestinya yang diatur dalam hal konstituen, penelitian ini fokus pada kebijakan yang dikeluarkan oleh Baznas yang tertuang di dalam Peraturan Nomor 2 tahun 2016 pasal 7 ayat (1) dan pasal 8 tentang tugas dan fungsi UPZ yang sebagaimana dimaksudkan adalah keberadaan Unit Pengumpul Zakat untuk membantu menghimpun mengelola, mendistribusikan, mendayagunakan dan lain sebagainya tentang zakat infak dan sedekah. Pada persoalan ini yang kemudian di spesifikasikan dalam hal pendistribusian Unit Pengumpul Zakat di Universitas Padjadjaran. 
Misalnya dalam hal zakat, pendefinisian distribusi dalam hal zakat yakni penyaluran zakat kepada orang yang berhak menerima (mustahik) baik secara konsumtif ataupun produktif. Upaya yang dilakukan mengenai evaluasi kebijakan tersebut adalah guna mempertegas arah kebijakan yang telah dirumuskan sebelumnya, agar amanat dari kebijakan itu terselenggara dengan baik yang akan berdampak pada kemaslahatan bersama. Berdasarkan kerangka pemikiran yang telah disebutkan dan agar dapat memudahkan untuk memahaminya, maka dibuatlah skema kerangka pemikiran yang dikonsep sebagai berikut:

Gambar 1.1

Kerangka Konsep Evaluasi Kebijakan Publik di Unit Pengumpul Zakat Universitas Padjadjaran

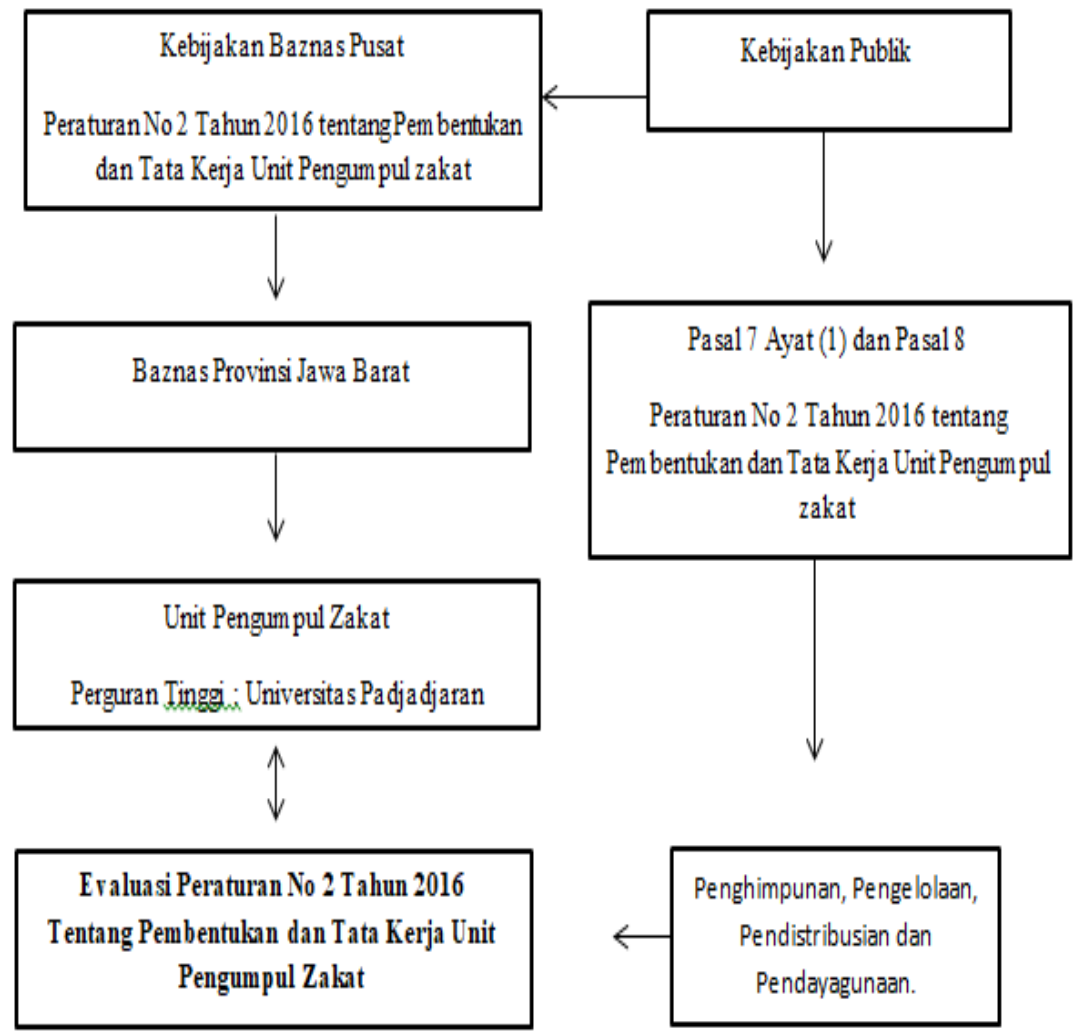




\section{Metode Penelitian}

Pendekatan penelitian yang digunakan adalah kualitatif dengan jenis penelitian deskriptif, yang bertujuan untuk memberikan kejelasan makna dari hasil penelitian. Penelitian deskriptif yaitu penelitian yang memberikan perhatiannya kepada masalah-masalah yang terjadi tatkala saat penelitian dilaksanakan. Penelitian ini diawali dengan adanya fenomena Peraturan No 2 Tahun 2016 tentang Pembentukan dan Tata Kerja Unit Pengumpul Zakat di Universitas Padjadjaran, dan di dalam pelaksanaanya Unit Pengumpul Zakat kampus tersebut tidak sebagaimana mestinya pada tata kerja yang di subordinasikan pada penghimpunan, pengelolaan dan yang lebih khusus perihal pendistribusian zakat infak dan sedekah. Sehingga peneliti tertarik untuk mulai meneliti hal ini yang dibantu oleh kajian data data dari informasi yang beredar, kajian pustaka dan lain sebagainya.

Untuk memperoleh data dan informasi yang diperlukan di dalam penelitian ini, maka ada beberapa teknik pengumpulan data yang digunakan dalam penelitian ini diantaranya teknik observasi, teknik wawancara dan dokumentasi. Beberapa informan penelitian yang dituju oleh peneliti berjumlah enam orang, diantaranya sebagai berikut:

a. Hadiyanto A. Rachim, sebagai pengawas dan penasehat UPZ Unpad

b. Gigin G.K Basar. sebagai Ketua UPZ Unpad

c. Dudi, sebagai Sekretaris UPZ Unpad

d. Muhamad Septian Rizki, sebagai Asisten Sekretaris UPZ Unpad

e. Yusup Mulyana adalah mahasiswa Unpad semester lima jurusan sastra arab dan saat ini sebagai Ketua Umum di kepengurusan program cinta kata 
f. Dian Elok adalah mahasiswi Unpad semester tujuh jurusan kedokteran dan saat ini sebagai Sekretaris Umum di kepengurusan program cinta kata.

\section{Hasil dan Pembahasan}

Proses pelaksanaan evaluasi yang telah dilakukan oleh pihak UPZ Unpad dilandasi melalui peraturan nomor 2 tahun 2016 tentang pembentukan dan tata kerja unit pengumpul zakat pada pasal 11 ayat 6 poin B yang berbunyi pengurus UPZ bertugas: melakukan evaluasi atas pelaksanaan tugas dan fungsi UPZ.

UPZ dalam hal melakukan tugas dan fungsinya yakni membantu BAZNAS Provinsi untuk menghimpun, mengelola, mendistribusikan dan mendayagunakan zakat, infak dan sedekah. Peran UPZ dalam tugas dan fungsinya itu untuk menyejahterakan para mustahik dengan cara mendistribusikan dana zakat, infak dan sedekah dari para muzaki kepada para mustahik yang ada di lingkungan Unpad. Kelompok muzaki yang turut terlibat dalam lembaga UPZ Unpad adalah para dosen yang ada dilingkungan Unpad. Adapun para mustahik yang ada dilingkungan Unpad terbagi menjadi dua, yaitu internal dan eksternal. Internal meliputi para mahasiswa/I dan karyawan yang secara finansial kurang mampu dan eksternal meliputi masyarakat sekitar yang ada dilingkungan Unpad Jatinangor Sumedang Jawa Barat

Peneliti dalam melakukan penelitiannya mengenai proses pelaksanaan evaluasi yang telah dilakukan oleh pihak UPZ Unpad ditempat penelitian didukung oleh teori William $\mathrm{N}$ Dunn. Di dalam teori William N Dunn dijelaskan bahwa syarat keberhasilan evaluasi itu ada enam, diantaranya: efektivitas, efisiensi, kecukupan, perataan, reponsivitas dan ketepatan. 
Pertama, dimensi efektivitas yang dimaksud dalam melakukan evaluasi terhadap suatu kebijakan merujuk kepada pembahasan yang mencakup hasil dari kebijakan itu. Maksudnya adalah kebijakan yang telah diimplementasikan akan mendapatkan hasil yang sesuai dengan cita cita dari kebijakan itu dibentuk.

Adapun dari dimensi efektivitas bahwa proses pelaksanaan evaluasi oleh elemen elemen yang ada di UPZ Unpad itu masih terdapat kekurangan kekurangan di dalamnya diantaranya yang pertama, belum ada SOP yang jelas dan frekuensi jalannya evaluasi. Maka yang seharusnya ditetapkan enam bulan sekali, namun ada pelaksanaan evaluasi yang tidak terencana. Kedua, target dari pelaksanaan evaluasi oleh pihak UPZ Unpad untuk kedepannya hanya menghasilkan rekomendasi rekomendasi yang belum pasti. Namun, karena masih dapat dikatakan cukup baru maka UPZ Unpad dalam waktu yang bersamaan berupaya untuk menyusun peta 2016 - 2020 agar menjadi standar acuan unit pengelola zakat ditingkat perguruan tinggi.

Kedua, dimensi efisiensi. Pembahasan efisiensi disini merupakan kebijakan yang telah dirumuskan harus sesuai dengan hasil yang diharapkan. Efisensi dalam hal proses pelaksanaan evaluasi dalam hal ini adalah "Seberapa banyak usaha yang diperlukan untuk mencapai hasil yang diinginkan?” Upaya apa saja yang diperlukan oleh pengurus UPZ Unpad untuk mencapai target dari kewenangan tugas dan fungsinya yang tidak membuang buang waktu tenaga dan biaya yang banyak. 
Dalam proses pelaksanaan yang telah dilakukan oleh pihak UPZ Unpad mengenai dimensi efisiensi bahwa UPZ Unpad memiliki upaya mengadakan sistem kaderisasi untuk merekrut tenaga tenaga baru dalam membantu kerja tugas dan fungsi dari UPZ Unpad. Sistem kaderisasi tersebut memberikan sarana edukasi bagi mahasiswa/I yang telah diseleksi oleh pengurus UPZ Unpad. Kedua, UPZ Unpad berupaya untuk bekerjasama dengan pihak ketiga saat program dan kegiatan yang sedang dilaksanakannya.

Dari kedua hal tersebut bahwa peneliti menganalisa mengenai keefisienan evaluasi yang dilakukan oleh pengurus UPZ Unpad. Pertama, keefisienan waktu yang digunakan membutuhkan waktu yang banyak, karena dalam sistem kaderisasi tentu tidak cukup sehari atau dua hari dilakukan sedangkan tugas dan fungsi serta program harus berjalan secara kontinuitas. Kedua, keefisienan tenaga yang digunakan cukup menguras dikarenakan Sumber Daya Manusia di dalam struktural pengurus UPZ Unpad masih minim.

Ketiga, Dimensi dari kecukupan ini membahas mengenai "seberapa jauh pencapaian hasil yang dihendaki dapat mengatasi suatu masalah?”. Hasil pelaksanaan evaluasi yang telah dilakukan oleh pengurus UPZ Unpad adalah mengenai rekomendasi rekomendasi yang berfungsi sebagai pemecahan dari permasalahan permasalahan yang ada diruang lingkup kinerja ataupun program kegiatannya. Selain itu, upaya yang dihasilkan dari kinerja pengurus UPZ Unpad untuk mencapai target dari kebijakan secara keseluruhan belum maksimal.

Berdasarkan hasil wawancara yang dilakukan oleh peneliti mengenai dimensi kecukupan bahwa pengurus UPZ Unpad sejauh ini dari tugas fungsi serta kinerja yang telah dievaluasi sudah optimal, akan tetapi di dalam upayanya tersebut tidak terlepas dari kekurangan kekurangan yang dimiliki, diantaranya sumber daya manusia yang masih terbatas, kebutuhan mustahik tidak sebanding dengan apa yang diberikan oleh muzaki dilingkungan 
Unpad kepada pihak UPZ Unpad, program program yang ada belum begitu mendorong dari keberadaan lembaga dan pentingnya dana zakat infak sedekah bagi kemaslahatan bersama. Hal ini mengindikasikan bahwa pentingnya diadakan evaluasi agar kondisi yang ada dapat diketahui dengan baik serta dapat diselesaikan secara bersama sama dan keseluruhan.

Keempat, dimensi perataan. Pembahasan dari dimensi perataan mencakup kepada pelaksanaan evaluasi yang dilakukan secara menyeluruh atau sebaliknya, hasil dari evaluasi tersebut semua pengurus UPZ Unpad mendapatkan tanggungjawab secara merata dan tugas fungsi yang dilakukan oleh pengurus UPZ Unpad dilaksanakan kepada target yang dituju atau sebaliknya.

Adapun yang dianalisa oleh peneliti atas hasil wawancara mengenai dimensi perataan bahwa evaluasi yang dilakukan seharusnya dibahas secara keseluruhan baik itu yang sifatnya kualitas ataupun kuantitas. Selain itu, dari tugas fungsi UPZ Unpad dalam tahap sosialisasi harus adanya jadwal yang dirumuskan dan membuat sebuah konsep agar target dari sosialisasi tersebut jelas agar citra dari lembaga diketahui oleh semua unsur unsur yang ada di Unpad sehingga keberadaan UPZ Unpad begitu penting untuk para mustahik.

Kelima, Dimensi Responsivitas membicarakan mengenai "Apakah hasil kebijakan memuaskan kebutuhan, preferensi, atau nilai nilai kelompok tertentu?". Dalam pembahasan dimensi responsivitas mencakup kepada bagaimana pelaksanaan evaluasi dan tugas fungsi oleh pengurus UPZ Unpad tersebut dapat memberikan hasil yang dapat berpengaruh terhadap kepuasan kinerja dan kebutuhan aspek diluar daripada pengurus UPZ Unpad. 
Berdasarkan hasil wawancara tersebut mengenai dimensi responsivitas peneliti menganalisa bahwa pemberian dana zakat infak dan sedekah oleh pihak UPZ Unpad belum adanya survey yang dilakukan oleh lembaga mengenai kepuasan dari pelayanan dan pemberian dana zakat infak sedekah kepada mustahik, hal ini akan berdampak kepada respon dari unsur unsur di Unpad mengenai jumlah dana yang masuk dari muzaki dan yang dikeluarkan kepada mustahik.

Keenam, Dimensi Ketepatan membicarakan mengenai “Apakah hasil (tujuan) yang diinginkan benar benar berguna atau bernilai?". Dalam pembahasan dimensi ketepatan mencakup kepada aspek bagaimana hasil dari pelaksanaan evaluasi yang dilakukan oleh pengurus UPZ Unpad tersebut dapat memberikan nilai yang berguna bagi UPZ Unpad dan lingkungan disekitarnya.

Berdasarkan hasil wawancara dari dimensi ketepatan diketahui bahwa tugas dan fungsi yang dimiliki oleh pengurus UPZ Unpad masih kurang dalam tahap sosialisasi, hal ini berdampak keberadaan UPZ Unpad yang belum semua diketahui oleh unsur unsur yang ada dilingkungan Unpad seperti, dosen mahasiswa dan karyawan.

Adapun pelaksanaan evaluasi yang dilakukan oleh pengurus UPZ Unpad hasilnya adalah rekomendasi rekomendasi yang berguna untuk meningkatkan kinerja, program yang dimiliki dan Sumber Daya Manusia di UPZ Unpad serta didukung oleh beberapa unsur unsur yang mengetahui akan keberadaan UPZ Unpad. 


\section{Faktor Kendala Evaluasi Kebijakan UPZ Unpad}

Dilihat dari dimensi efektivitas, pihak UPZ Unpad telah melakukan evaluasi dengan cukup baik kepada seluruh jajaran pengurus UPZ Unpad meskipun dalam hal pelaksanaan evaluasi tersebut pihak UPZ Unpad melaksanakannya setiap enam bulan sekali namun masih tetap berjalan dengan baik dan juga saat ada hal yang penting sekali, pengurus UPZ Unpad langsung melakukan evaluasi, sebagaimana pernyataan dari Ketua UPZ Unpad, Dr Gigin G.K Basar, S.Sos., MM : “Kendalanya itu kita cuman melaksanakan evaluasi setiap enam bulan sekali, kan itu cukup lama juga, tapi kita juga melakukan evaluasi kalau ada hal hal yang sangat urgen untuk lancarnya tugas dan fungsi yang dimiliki oleh UPZ Unpad, karena kita baru juga yah kita selalu meningkatkan citra dari UPZ Unpad agar dipandang memang lembaga ini sangat penting apalagi dilingkungan kampus (Wawancara 09 Agustus 2018)

Selanjutnya, dilihat dari dimensi efisiensi mengenai pelaksaan evaluasi ini adalah sejauh mana upaya yang dilakukan untuk mencapai tujuan yang dicita citakan. Setelah peneliti menganalisis hasil wawancara dan observasi, masih terdapat kekurangan sumber daya manusia untuk mencapai tujuan dari kebijakan yang dicita citakan.

Permasalahan Sumber Daya Manusia dan Atmosfer yang kurang mendukung dilingkungan Unpad menjadi kendala atas keefisienan jalannya tugas dan fungsi UPZ Unpad dari evaluasi yang dilaksanakan. Sebagaimana dijelaskan oleh Pengawas UPZ Unpad, Hadiyanto A. Rachim:

"Kendala yang pertama itu SDM nya, SDM sudah sangat jelas, jadi ini keliatannya cukup signifikan, yang kedua atmosfer yah, zakat ini kan belum menjadi sebuah apa yah dilingkungan akademik yah khususnya Unpad, belum menjadi sesuatu bahwa ini adalah harus dilaksanakan, jadi belum mengikat gitu yah kesannya itu, nah jadi saya kira ini juga menjadi kendala lingkungan atmosfer yang belum sepenuhnya mengenal kiprah dari UPZ. Apa itu UPZ? Mau apa UPZ? Gitu yah seperti itu. Itu juga menurut 
saya yah kendala, jadi artinya apa, ya memang ini perlu kerja keras dan kerja keras itu tadi untuk SDM yang mengerti yang memahami gitu yah, masalah UPZ, orientasi UPZ dan semuanyalah berbicara tentang kemaslahatannya dan sebagainya. Orang itu taunya kalau udah maju baru apa, ngincer ngincer UPZ, kalau belum masih repot gini mah biarin aja terus aja dikritik, tapi kalau udah maju kritik juga, wah kritik tidak transparan dan sebagainya. Bisa aja begitu, akhirnya ujung ujungnya iming iming ambil alih gitu yah, biasanya sepert itu dalam organisasi". (Wawancara 16 Oktober 2018).

Kemudian jika dilihat dari dimensi kecukupan, setelah menganalisis hasil wawancara, terdapat masalah di sistemnya. Jadi sistem yang digunakan untuk pelaksanaan evaluasi adalah sistem opsional, pengurus UPZ Unpad hanya fokus terhadap peningkatan kualitasnya saja, aspek kuantitas juga hakikatnya dapat berpengaruh terhadap kelancaran dari tugas dan fungsi yang dilaksanakan oleh pengurus UPZ Unpad. Misalnya, ketika Sumber Daya Manusia yang ada di UPZ Unpad jumlahnya minim maka pihak UPZ Unpad yang secara teknis menjadi kesulitan dalam melakukan hal apapun yang harus dikerjakannya pada waktu tertentu, sebagaimana dijelaskan oleh Sekretaris UPZ Unpad, Dudi:

"Kita dalam melakukan evaluasi yah hanya dipeningkatan kualitasnya aja, untuk di aspek kauntitas kita memang kekurangan, namun dari situ kita punya alternatif lain yaitu memberdayakan mahasiswa untuk menjadi relawan dari program kegiatan yang dilaksanakan oleh pihak UPZ Unpad”. (Wawancara 08 Agustus 2018).

Selanjutnya, dilihat dari dimensi perataan mengenai pelaksanaan evaluasi yang dilakukan oleh pengurus UPZ Unpad bahwa kendalanya adalah pertama dibagian mengatur jadwal kerja pengurus dalam menjalankan tugas dan fungsi UPZ Unpad. Hal ini disebabkan, struktural pengurus UPZ Unpad semuanya dosen yang mana ada kesibukkan mengajar, rapat dan lain sebagainya yang memang tidak mungkin untuk selalu dikantor UPZ Unpad. 
Namun untuk pendistribusian dana zakat infak dan sedekah kepada para mustahik sudah merata, seperti apa yang diutarakan oleh Ketua UPZ Unpad, Gigin G.K Basar:

"Iya kan kita semua pengurus ini dosen yah, jadi agak terlalu sulit untuk membagi bagi waktunya, tapi kita juga mengatur kok pasti ada aja pengurus yang dikantor, kita bagi bagi waktu aja sama pengurus yang lain terkadang kalau ga ada sama sekali kita kan punya asisten dan itu bukan dari dosen, bisa untuk diandalkan. Kalau perihal pendistibusian dana zakat yah kita sudah bagi dengan poris sama rata". (Wawancara 09 Agustus 2018).

Dari dimensi responsivitas mengenai pelaksanaan evaluasi yang dilakukan oleh pengurus UPZ Unpad bahwa kendalanya adalah di dalam tugas dan fungsi UPZ Unpad pada aspek sosialisasi. Yang mengakibatkan respon kurang baik dari unsur unsur yang ada dilingkungan Unpad yaitu karena keberadaan UPZ Unpad masih belum diketahui dengan jelas. Sosialisasi yang dilakukan oleh pihak UPZ Unpad masih mengandalkan even even tertentu saja, dan belum ada rutinitas yang terjadwalkan, sebagaimana apa yang diutarakan oleh pengawas UPZ Unpad, Hadiyanto A. Rachim:

"Dari aspek sosialisasi kan kita kurang, kemudian yah ga ada jadwal yang pasti untuk sosialisasi ini, kalau ada kesempatan untuk sosialisasi yah kita sosialisasi, tapi kalau ga ada kita menjalankan tugas fungsi yang rutinan dan program kegiatan yang ada saja”. (Wawancara 16 Oktober 2018).

Terakhir, dilihat dari dimensi ketepatan, hal yang menjadi kendala utama dalam pelaksanaan evaluasi ini ialah dari sisi teknis pengelola dari tiap bidang belum maksimal, dari sisi tugas dan fungsi adalah dibagian sosialisasi masih kurang dan dari sisi sistem evaluasi oleh pihak UPZ Unpad yang stagnan. Sebagaimana dijelaskan oleh pengawas UPZ Unpad Hadiyanto A. Rachim: 
"Yah sampai saat ini dalam mengawasi sekaligus dari penilaian yang saya punya terkait aktivitas baik itu rutinan ataupun insidental yang dilakukan UPZ Unpad itu yah dari sisi teknis, pengelola tiap bidang itu belum maksimal, diakui melaksanakan even even tertentu romadhon itu kita bertanggung jawab untuk penyaluran gitu kan, tapi kalau sesuai rutinitas itu relatif stagnan yah, tapi kalau dalam even tertentu yah didorong kayak kita melakukan sosialisasi yah cuman even tertentu aja, terus kalau rutinitas seperti ini jarang ada dosen yang stay di kantor UPZ, itu jarang sekali”. (Wawancara 16 Oktober 2018).

\section{Dampak Impilkasi dari Kendala Terhadap Eksistensi UPZ Unpad}

Tugas dan Fungsi yang dilakukan oleh pengurus UPZ Unpad menggunakan peraturan No 2 Tahun 2016 Tentang Pembentukan dan Tata Kerja Unit Pengumpul Zakat yakni sosialisasi dan edukasi, pengumpulan, pendataan dan layanan muzaki, pengelolaan, pendistribusian dan pendayagunaan zakat infak dan sedekah. Tentu hal ini pengurus UPZ Unpad harus mentaati peraturan yang digunakan dan disokong dengan kebijakan kebijakan di internal pengurus UPZ Unpad tersebut yang tidak menyimpang dari peraturan yang melandasinya.

Berdasarkan hasil wawancara, observasi dan kajian pustaka yang dilakukan oleh peneliti bahwa tugas dan fungsi yang dilakukan oleh pengurus UPZ Unpad yang begitu besar dampaknya atas eksistensi kelembagaan yaitu sosialisasi dan edukasi zakat infak dan sedekah.hal ini didasarkan atas pernyataan dari, Ketua UPZ Unpad, Gigin G.K Basar: "Yang membuat UPZ Unpad dikenal atau dinilai baik dan penting kan dari aspek sosialisasinya. Udah harga mati ketika sosialisasi ini terhenti, artinya balik lagi kepada keberadaan lembaga. Apakah lembaga ini hanya memperbanyak gedung dan lapangan kerja aja dilingkungan Unpad? Atau lembaga yang mengurusi zakat dimomen momen tertentu saja dan lembaga yang 
tak menjadi perhitungan? Kan itu konsekuensinya ketika sosialisasi tidak maksimal. Gitu kan, jadi ini begitu besar dampaknya atas keberadaan UPZ Unpad kedepannya”.

Kemudian, tugas dan fungsi yang memiliki dampak atas eksistensi UPZ Unpad adalah sistem pengelolaan dan pendistribusian yang digunakan. Dari aspek pengelolaannya UPZ Unpad belum maksimal karena masih mengandalkan even even tertentu saja yang menggaet pihak ketiga untuk berjalannya program kegiatan yang dimiliki. Dan hal tersebut akan berdampak kepada sudut pandang serta penilaian dari para muzaki yang selalu memberikan dana zakat infak dan sedekah kepada UPZ Unpad atas kredibilitas dalam hal mengelola untuk didistribusikan kepada para mustahik dilingkungan Unpad.

Diketahui bahwa secara garis besar sistem pengelolaan dan pendistribusiannya masih stagnan dan kaku. Terkhusus pendistribusian dana zakat infak dan sedekah, pihak UPZ Unpad memiliki program program kegiatan untuk menunjang tugas dan fungsi dari UPZ Unpad tersebut. Selain itu, belum adanya inisitaif lain untuk melakukan perubahan demi terciptanya kemaslahatan bersama yakni targetnya adalah para muzaki dan mustahik. Hal ini menjadi dampak implikasi dari kendala yang ada terhadap eksistensi UPZ Unpad dalam jangka waktu pendek atau panjang. 


\section{Simpulan}

Proses pelaksanaan evaluasi kebijakan yang dilakukan oleh pengurus UPZ Unpad telah berjalan dengan rutin, namun belum efektif. Berdasarkan teori evaluasi kebijakan dari Dunn pada dimensi efektivitas masih belum mencapai hasil yang diinginkan. Sedangkan dalam dimensi efisiensi, pelaksanaan evaluasi kebijakan memiliki upaya untuk memecahkan masalah melalui hasil presentasi dari setiap pengurus UPZ Unpad, hal tersebut adalah betuk rekomendasi rekomendasi yang akan meningkatkan kinerja, kualitas program dan koordinasi antar satu dengan yang lainnya. Selanjutnya pada dimensi kecukupan, pelaksanaan evaluasi kebijakan yang dilakukan oleh pengurus UPZ Unpad sejauh ini hanya mencapai tahap penghimpunan dan penyaluran saja melalui program - program kegiatan yang dimilikinya. Selanjutnya dari dimensi perataan ini, konteks tugas dan fungsi yang dilakukan oleh pengurus UPZ Unpad salah satunya pendistribusian sudah cukup merata, sedangkan perihal sistem pembagian kepada asnaf ada hal yang diprioritaskan.

Adapun pada pelaksanaan evaluasi yang dilakukan oleh pengurus UPZ Unpad kurang merata, dikarenakan hanya fokus kepada pembahasan yang sekiranya terdapat masalah yang menghambat jalannya kinerja pengurus. Selanjutnya dari dimensi responsivitas pada pelaksanaan evaluasi begitu antusias respon pengurus UPZ Unpad, namun terhadap para muzaki, mustahik dan unsur unsur dilingkungan Unpad masih belum semuanya masuk dalam kategori memuaskan dan baik baginya. Sebab dari tugas dan fungsi pada aspek sosialisasi dan edukasi masih kurang. Selanjutnya dari dimensi ketepatan pada pelaksanaan evaluasi ini memberikan hasil yakni rekomendasi rekomendasi yang berguna bagi keberadaan UPZ Unpad maupun kebaikan kinerja pengurus untuk menyusun jalan peta menjadi standar acuan pengelola zakat di tataran perguruan tinggi. 


\section{Referensi}

Agustino, L. (2012). Dasar-Dasar Kebijakan Publik. Jakarta: CV. Alfabeta

Dunn, W. (1990). Public Policy Analysis: An Introduction. United States of America: Englewood Cliffs, Prentice Hall Inc. . (2003). Pengantar Analisis Kebijakan Publik Edisi Kedua, Yogyakarta: Gadjah Mada University Press

Hafidhuddin, D. (2008). The Power of Zakat Studi Perbandingan Pengelolaan Zakat Asia Tenggara. Malang: UIN-Malang Press.

Lintjewas, O., Tulusan, F., \& Egetan, M. (2012). Evaluasi Kebijakan Pemberian Pengembangan Usaha Mina Perdesaan di Kabupaten Minahasa Selatan. Society: Jurnal Ilmu Sosial \& Pengelolaan Sumberdaya Pembangunan, 2 (20), 82-95

Miles, M. B., \& Huberman, A. M. (2009). Analisis Data Kualitatif. Jakarta: UI Press.

Moleong, J. L. (2006). Metodologi Penelitian Kualitatif. Bandung: PT. Remaja Rosdakarya.

Nugroho, R. (2009). Public Policy. Jakarta: PT. Elex Media

Peraturan Undang Undang Nomor 23 Tahun 2011 tentang Pengelolaan Zakat.

Peraturan Nomor 2 Tahun 2016 Tentang Pembentukan dan Tata Kerja Unit Pengumpul Zakat.

Poerwadaminta, W.H.S. (1991). Kamus umum Indonesia. Jakarta: Balai Pustaka. 
Sholehuddin. (2005). Shaleh al-Fuzan, Fiqih Sehari-Hari, alih bahasa oleh Abdul Hayyie Al Khatani dkk, Depok: Gemma Insani Press.

Sugiyono. (2014). Memahami Penelitian Kualitatif. Bandung: Alfabeta Komputindo. (2014). Memahami Penelitian Kualitatif. Bandung: Alfabeta.

Subarsono, A.G. (2005). Analisis Kebijakan Publik: Konsep, Teori, dan Aplikasi. Yogyakarta: Pustaka Belajar . (2011). Kebijakan Publik: Konsep, Teori, dan Aplikasi. Yogyakarta: Pustaka Pelajar.

Suharto, E. (2008). Kebijakan Sosial Sebagai Kebijakan Publik. Bandung: Alfabeta

Siagian, S.P. (2008). Manajemen Strategi. Jakarta: Rineka Cipta

Suparman, N., Sakti, F.T, Engkus. (2018). Evaluasi Program KB pada Era Desentralisasi di Kuningan Jawa Barat. Jurnal JPPUMA 6(2). 122-131.

Suparman, N. (2018). Evaluasi Kebijakan Pelimpahan sebagian Kewenangan Bupati kepada Camat di Kecamatan Sagalaherang kabupaten Subang tahun 2015. Jurnal Indonesian Political Science Review 2 (2). 159-178.

Suparman, N, Chandra, D, Sari, A. L. (2019). Bureaucratic Behavior in the Implementation of Capital Expenditure Budget in the Office of Public Work and Spatial Planning of Sumedang Province. Jurnal Bina Praja: Journal of Home Affairs Governance 11 (1). 99-109. 
Tangkilisan, H.N. (2003). Manajemen Publik. Jakarta: Grasindo

Qardhawi, Y. (2005). Spektrum Zakat dalam Membangun Ekonomi Kerakyatan. Jakarta: Zikrul Hakim.

Wahab, S.A. (2007). Analisis Kebijaksanaan Dari Formulasi Ke Model Implementasi Kebijaksaan Publik. Jakarta: Bumi Aksara

Wibawa, S. (2002). Evaluasi Kebijakan Publik. Jakarta: Grafindo Persada

Widodo, J. (2009). Analisis Kebijakan Publik: Konsep dan Aplikasi Analisis Proses Kebijakan Publik. Malang: Bayumedia Publishing

Winarno, B. (2002). Kebijakan Publik: Teori dan Proses. Yogyakarta: Media Presindo

Wiyoto, B. (2005). Mengembangkan Riset Strategik Implementasi Kebijakan Publik Perspektif Good Governance. Malang: Partner Consulting 